\title{
Effectiveness of Moringa Oleifera Seed as Phytocoagulant in Wastewater Treatment of Batik Industry
}

\author{
Erina Rahmadyanti ${ }^{1}$, Elizabeth Titiek Winanti ${ }^{2}$, Indiah Kustini ${ }^{3}$ \\ Departement of Civil Engineering \\ Universitas Negeri Surabaya \\ Surabaya, Indonesia \\ 12erinarahmadyanti@unesa.ac.id, ${ }^{2}$ titiekwinanti@unesa.ac.id, ${ }^{3}$ indiahkustini@unesa.ac.id
}

\begin{abstract}
Investigating effectiveness of Moringa oleifera seed as environmentally-friendly phytocoagulant to reduce pollutant in batik industry wastewater has been conducted for period of times. This study found that processing coagulation flocculation independently was proved ineffective for batik industrial wastewater treatment. $\mathrm{pH}$ was variable that met effluent standards set by government, while other two variables, BOD and COD, did not meet the standard set, as both increased along with the increasing dose of Moringa oleifera. The increase of BOD and COD was probably caused by the oil content which was not extracted from the seeds. Although TDS variable showed significant reduction between $66 \%-92 \%$, it did not meet effluent standard set by government. This study suggested that future research should add an independent variable, such as variations of rapid stirring, $\mathrm{pH}$ variations, or oil extraction. In addition, combining several processing methods and adding different dose of Moringa oleifera seeds can be also another option. These are to possibly see the effectiveness of the flocculation-coagulation process independently as well as the combination of them in the wastewater treatment of batik industry.
\end{abstract}

Keywords-Moringa oleifera; phytocoagulant; Batik industry

\section{INTRODUCTION}

Water is very important for national economic growth. Its availability from its quantity, quality and continuity is an absolute necessity. However, it becomes major problem in many developing countries where the industrial growth, especially Small and Medium Enterprises (SMEs) rapidly emerge. SMEs are the largest business sector in the world economy and produce the majority (up to 60\%) of global economic output. This large amount is accompanied by the large contribution of environmental pollution which reaches $60-70 \%$ of total pollution. This makes SMEs becoming the cause for environmental pollution worse than large industries [1].

Similar conditions also occur in Indonesia. In Indonesia, SMEs are economy backbone. One of them is batik industry, a creative industry that becomes one of national concern. Most of regions in Indonesia have batik industry which shows regional characteristics. Throughout Indonesia, there are 101 batik industry centres, some of them were in Java, such as Central Java, West Java, East Java, and Yogyakarta D.I. A number of workers employed were more than fifteen thousand people.
Yet, it is continually growing $67 \%$ per year averagely, in which $80 \%$ of the products are for domestic market with only $20 \%$ of them for export. The Ministry of Industry noted that by 2017, the export value of batik products were around USD 51.15 million, it increased from USD 39.4 million in the first semester. The main markets for batik were Japan, United States, and Europe. So, 3\% increase per year becomes a target value for batik export [2].

Besides the magnitude of its contribution to Indonesian economy, there are particular concerns from it, one of them is related to the environment. The increasing percentage of exports certainly affect on the increasing capacity of batik production as well as the amount of wastewater discharged into the environment. As known, the characteristics of batik industry are limited capital, knowledge, and equipment. Limited capital causes most of batik industry having no proper wastewater treatment. The wastewater generated from production process was directly discharged into drainage channels and body water. In batik production, dyeing process uses chemicals such as acid dyes, alkaline dyes, direct dyes, reactive dyes, naphthol dyestuffs and vessel dyestuffs. Those various dyes become wastewater with high dyes, Biological Oxygen Demand (BOD), and Biological Oxygen Demand (COD) contents [2]. This wastewater when directly discharged into the body of water without undergoing any treatment process will cause resource depletion, water pollution, water scarcity, and disease [3]. In long run, it disturbs social and economic development [4].

For the sustainability of clean water availability in the future, the discharged wastewater must meet standards set by government. Therefore, it is necessary to use a simple technology for wastewater treatment with low operational costs, no special requirement (easy to operate), and high efficiency, so it can be continuously implemented in SMEs[5]. One of technologies possibly implemented is coagulationflocculation.

Coagulation is one of the most common ways to reduce the pollutants in water such as turbidity, color, organic matters, and metal ions. Separating colloids is done by adding synthetic coagulants (Ferrous sulphate, aluminium sulphate, and poly aluminium chloride) and followed by slow agitation (flocculation), so the particles are precipitated [6]. The 
effectiveness of using chemicals as coagulants is well known, however those have some disadvantages such as high operating costs, high maintenance, and high mud volume. In addition, using chemical coagulants in a certain dose endanger humans and environment when it was not carried out correctly and properly. Using aluminium ions with concentrations more than $50 \mu \mathrm{g} / \mathrm{L}$ are potentially toxic for fish and aquatic organisms [7][8]. There were studies reporting that if wastewater treatment was not appropriate, aluminium ions used as coagulants potentially cause Alzheimer's disease [6][9]. Therefore, environmentally-friendly and safe coagulants are needed.

One of environmentally-friendly and safe coagulants for humans is Moringa oleifera seeds. Moringa oleifera seeds produced by Moringa oleifera lam plants are native plants from the sub-Himalayan regions such as India, Pakistan and Afghanistan [10]. Although it is not Indonesian native vegetations, Moringa oleifera plants are easily found. The advantages in using Moringa oleifera for wastewater treatment are cost-effective, possibly to use for extreme $\mathrm{pH}$ and high level biodegradability [11][12]. In addition, Moringa oleifera helps in particles and microorganisms aggregation in which possibly controls the spread of disease [13][14]. Moringa oleifera seeds also benefits when it is consumed by people with anaemia [13]. This study aims to determine the effectiveness of Moringa oleifera seeds as an environmentally-friendly phytocoagulant in reducing various pollutant contents in batik industry wastewater.

\section{MethodOlOGY}

\section{A. Sample collection and handling}

The wastewater used in this study was the staining wastewater in batik production. Samples were taken from one of Batik SMEs in Surabaya. APHA standards were used for collection and storage to ensure the less influence on distribution systems of water samples [15]. The samples were analyzed within 5 to 14 days after collection. The results indicated that all observed parameters were beyond the standards set out by government in the Decree of the Governor of East Java No. 72/2013.

TABLE I. RESUlT OF CHARACTERISTICS TEST OF BATIK DYEING WASTE

\begin{tabular}{|c|c|c|c|c|c|}
\hline No & Parameter & $\begin{array}{c}\text { Analysis } \\
\text { Methods }\end{array}$ & Unit & $\begin{array}{c}\text { Analysis } \\
\text { Result }\end{array}$ & $\begin{array}{c}\text { Standard } \\
\text { Set } \\
\text { Decree of } \\
\text { Governor of } \\
\text { East Java } \\
\text { No. } \\
72 / 2013\end{array}$ \\
\hline 1 & $\mathrm{pH}$ & $\mathrm{pH}$ meter & - & 5.48 & $6-9$ \\
\hline 2 & $\mathrm{TSS}$ & Gravimetric & $\mathrm{mg} / \mathrm{L}$ & 1,236 & 50 \\
\hline 3 & $\mathrm{COD}$ & Reflux & $\mathrm{mg} / \mathrm{L} \mathrm{O}_{2}$ & 3,962 & 150 \\
\hline 4 & BOD & Winkler & $\mathrm{mg} / \mathrm{L} \mathrm{O}_{2}$ & 2,820 & 60 \\
\hline 5 & Oil and fat & Gravimetric & $\mathrm{mg} / \mathrm{L}$ & 70 & 3 \\
\hline
\end{tabular}

\section{B. Seed preparation and treatment}

Moringa oleifera pods were manually opened to get the seeds, and then dry them. The kernel was ground in a domestic blender and filtered through a $600 \mu \mathrm{m}$ stainless steel filter [3]. After that, flour kernels are sifted. 5 grams of Moringa seeds powder were added to $100 \mathrm{~mL} 1 \mathrm{M} \mathrm{NaCl}$ solvent solution. The suspension is mixed with a magnetic stirrer for 10 minutes to release the active component of the seed in water. The solution was then filtered with a $47 \mathrm{~mm}$ glass microfiber filter (Whitman International, Ltd) to separate the remaining seed particles from the solution. The result is a clear white liquid. The supernatant is poured and the remaining solids are dried (seed cake) at room temperature for 24 hours. Filtered extracts were used in this experiment.

\section{Wastewater treatment}

Wastewater treatment was carried out according to jar test normalization since recommended as the most suitable mechanism for coagulant activity [16]. The stock solution was created by adding Moringa oleifera seed cake with several concentrations to create coagulant paste. Concentration of Moringa oleifera seed cake varied from 50, 100, and $150 \mathrm{mg}$ was dissolved on distilled water to get 10,$000 ; 20,000$; and $30,000 \mathrm{mg} / \mathrm{L}$ [3][17]. $500 \mathrm{~mL}$ of batik wastewater was added into a beaker to determine the initial turbidity. The correct concentration of stock solution was then added into each beaker and placed into jar test apparatus with 6 places. The speed of fast and slow mix was used on $120 \mathrm{rpm}$ and $40 \mathrm{rpm}$ respectively for $20 \mathrm{~min}$. Beakers were then allowed to settle for one hour after the Jar Test. Subsequently, a sample was taken by a syringe $3 \mathrm{~cm}$ from the surface for further analysis.

\section{Analytical methods}

Measurement was conducted on raw wastewater as influent and effluent taken from coagulation-flocculation process to parameters of pH, BOD (Biological Oxygen Demand), COD (Chemical Oxygen Demand) and TDS (Total Dissolved Solid). $\mathrm{pH}$ was measured using $\mathrm{pH}$ meter. BOD was measured using BOD5 by defining the oxygen need from incubated sample for 5 days on temperature of $20^{\circ} \mathrm{C} \pm 1^{\circ} \mathrm{C}$. COD was determined by using dichromate closed reflux with spectrophotometer. TSS was determined using gravimetric of the residue dried to a constant weight at least $1 \mathrm{~h}$ at $103-105^{\circ} \mathrm{C}$.

\section{E. Statistical analysis}

The data were tested using an experimental design with SPSS 18 software. The dependent variables ( $\mathrm{pH}, \mathrm{BOD}, \mathrm{COD}$ and TDS) were analyzed in advance for their homogeneity using Lavene Test. Variables considered homogeneous if they had significance value more than 0.05. Furthermore, the independent variables (Moringa oleifera dose and sedimentation of time to the dependent variables both independently and together) were tested. The results were then further proved using the Pillai's Trace test results, Wilks Lambda, Hotelling Trace and Roy's Largest Root in the multivariate test. The significant influence of independent variables on the dependent variable was indicated by significant value $<0.05$. 


\section{RESULTS AND DISCUSSION}

\section{A. Result}

The degree of acidity $(\mathrm{pH})$ is one of the important factors that influence the coagulation process. If the coagulation process is not at optimum conditions, $\mathrm{pH}$ can fail to form floc impacting on the low quality of effluent produced by wastewater. Optimum $\mathrm{pH}$ of each coagulant is different. Optimally, $\mathrm{pH}$ value on Moringa oleifera is about 6-8. Here, amino acids ionize to produce carboxylated ions and protons, proton charge attracts electrons (collide) to form neutral groups and then produce floc [3].

$\mathrm{pH}$ value of batik industry wastewater was 5.48 meaning that it was below the effluent standard set by government. Adding Moringa oleifera dose was done using three different concentrations $(50 \mathrm{mg} / \mathrm{L}, 100 \mathrm{mg} / \mathrm{L}$, and $150 \mathrm{mg} / \mathrm{L}$ ) for each detention time of 45 minutes, 60 minutes and 120 minutes. Adding $50 \mathrm{mg} / \mathrm{L}$ of Moringa oleifera by $50 \mathrm{mg} / \mathrm{L}$ resulted in $\mathrm{pH}$ increase to $5.96 \pm 0.15$, adding $100 \mathrm{mg} / \mathrm{L}$ concentration increased $\mathrm{pH}$ to $6.46 \pm 0.07$, and adding $150 \mathrm{mg} / \mathrm{L}$ Moringa oleifera increased $\mathrm{pH}$ to $7.28 \pm 0.12$. The results indicated that $\mathrm{pH}$ increased along with the increasing dose of Moringa oleifera (Figure 1).

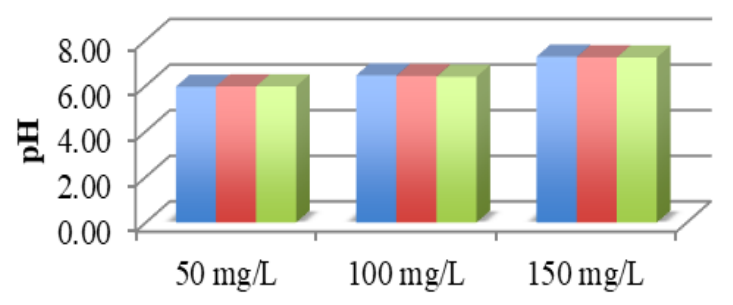

Moringa oleifera dose (mg/L)

$$
\text { — } 45 \text { minutes } \square 60 \text { minutes } \square 120 \text { minutes }
$$

Fig. 1. $\mathrm{pH}$ increase along with the increasing dose of Moringa oleifera for each detention time.

From three concentrations, adding $50 \mathrm{mg} / \mathrm{L}$ Moringa oleifera did not give an effluent standard set by government. However, at $100 \mathrm{mg} / \mathrm{L}$ and $150 \mathrm{mg} / \mathrm{L}$ doses of Moringa oleifera, $\mathrm{pH}$ value met the standard set (on 6-8)[18]. Table 1 shows the results of Pillai's Trace test, Wilks 'Lambda, Hotelling's Trace and Roy's Largest Root where the value was 0.000 or $<0.05$ indicating that the dose of Moringa oleifera affected the values of PH, BOD, COD and TDS.

TABLE II. RESULT FROM MULTIVARIATE ANALYSIS ON THE INFLUENCE OF MORINGA OLEIFERA DOSES TO PH, BOD, COD, TDS

\begin{tabular}{|c|c|c|c|c|c|}
\hline \multirow{2}{*}{ Effect } & Value & $\mathbf{F}$ & $\begin{array}{c}\text { Hypo- } \\
\text { thesis } \\
\text { df }\end{array}$ & $\begin{array}{c}\text { Error } \\
\text { df }\end{array}$ & Sig \\
\hline \multirow{2}{*}{$\begin{array}{l}\text { Pillai's Trace } \\
\text { Wilks' }\end{array}$} & 1.956 & 376.440 & 8.000 & 68.000 & .000 \\
\cline { 2 - 6 } $\begin{array}{l}\text { Lambda } \\
\sum_{1}^{\prime} \begin{array}{l}\text { Hotelling's } \\
\text { Trace }\end{array}\end{array}$ & .000 & $1894.465^{\mathrm{a}}$ & 8.000 & 66.000 & .000 \\
\cline { 2 - 6 } & 2347.064 & 9388.255 & 8.000 & 64.000 & .000 \\
\cline { 2 - 6 } \\
$\begin{array}{l}\text { Largest Root } \\
\text { Largest }\end{array}$ & 2325.198 & $19764.179^{\mathrm{b}}$ & 4.000 & 34.000 & .000 \\
\hline
\end{tabular}

$\mathrm{pH}$ increase also occurred in the ground water process using Moringa oleifera as a coagulant. Moringa oleifera is known as a natural cationic polyelectrolyte and flocculants with a basic chemical composition of polypeptide. It has a molecular weight between 6,000 - 16,000 Daltons containing 6 amino acids, mainly glutamic acid, methionine and arginine [10]. Cationic protein is water soluble in the seeds. This protein causes the reception of protons in water by the alkaline amino acids present in the Moringa oleifera protein resulting on the hydroxyl groups release which causing alkaline solution [10][19]. Another possibility causing $\mathrm{pH}$ increase is $\mathrm{CO} 2$ production during the aerobic degradation process of organic matter [3].

COD removal related to the reduction of organic materials suspended in wastewater. Moringa oleifera dose has significant effect on COD (see Table 1), as proved by results of the Pillai's Trace test, Wilks' Lambda, Hotelling's Trace and Roy's Largest Root where it was 0.000 or $<0.05$. Adding varied doses of Moringa oleifera $(50 \mathrm{mg} / \mathrm{L}, 100 \mathrm{mg} / \mathrm{L}$, and $150 \mathrm{mg} / \mathrm{L})$ did not result on the COD effluent met standard set $\mathrm{b}$ government (on $150 \mathrm{mg} / \mathrm{L}$ ). However, COD increased along with the increasing doses of Moringa oleifera (Figure 2).

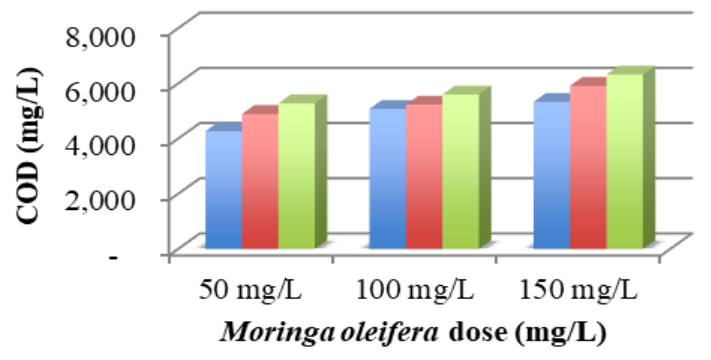

- 45 minutes $\square 60$ minutes $\square 120$ minutes

Fig. 2. CD increase on Moringa oleifera doses for each detention time

In batik wastewater, COD increased drastically from 3962 $\mathrm{mg} / \mathrm{L}$ to $4271-5277 \mathrm{mg} / \mathrm{Las}$ by adding $50 \mathrm{mg} / \mathrm{L}$ Moringa oleifer; to $5076-5594 \mathrm{mg} / \mathrm{L}$ by adding $100 \mathrm{mg} / \mathrm{L}$ Moringa oleifera; and to 5330-6321 by adding $150 \mathrm{mg} / \mathrm{L}$ Moringa oleifera. COD increase was $17 \%, 25 \%$, and $32 \%$ by adding 50 $\mathrm{mg} / \mathrm{L}, 100 \mathrm{mg} / \mathrm{L}$, and $150 \mathrm{mg} / \mathrm{L}$ Moringa oleifera respectively. This results was different from previous studies that used Moringa oleifera to treat tapioca industrial wastewater. Moringa is indicated to have a high ability to bind the organic matters suspended in tapioca starch wastewater [5]. However, the results of this study were similar to the findings of Arnoldsson et al [12]. Moreover, COD increased dramatically after the treatment because the oil content of Moringa oleifera seed was not completely removed. The organic matter in Moringa oleifera seed cake asissted to increase COD. Previous studies found that oil extraction was able to withstand COD increase during processing. Using $17 \mathrm{mg} / \mathrm{L}$ Moringa oleifera on tap water to treat low turbity 15 NTU wastewater resulted on COD increase $2 \mathrm{mgO} 2 / \mathrm{L}$ to $2.4 \mathrm{mgO} 2 / \mathrm{L}$. Besides, the solvent used to extract the oil from Moringa oleifera seed increased CODas well [12]. Increasing COD cannot be avoided when it was done in natural, direct extract matter. Although COD increased, it was not dangerous because organic matter is of the 
natural origin and no toxic effects that have been reported regarding Moringa oleifera seeds. Moreover, it might be a possible inconvenient factor if water were stored for longer period or treated with chlorine [20].

Moringa oleifera concentration had significant effect on BOD concentration as it was in line with Eman (see Table 1). It shows the significant value of 0.000 or $<0.05$ obtained (proved by the results of Pilai's Trace, Wilks 'Lambda, Hotelling's Trace and Roy's Largest Root). In Figure 3, BOD was boosted progressively by increasing Moringa oleifera dose. BOD increased by $14 \%$ at $50 \mathrm{mg} / \mathrm{L}$ addition of Moringa oleifera, $22 \%$ at $100 \mathrm{mg} / \mathrm{L}$, and $28 \%$ at $150 \mathrm{mg} / \mathrm{L}$. It resulted on the average BOD value of $3081-3543 \mathrm{mg} \mathrm{L}$ at $50 \mathrm{mg} / \mathrm{L}$ addition of Moringa oleifera, 3388-3781 mg/L at $100 \mathrm{mg} / \mathrm{L}$, and $3697-$ $4094 \mathrm{mg} / \mathrm{L}$ at $150 \mathrm{mg} / \mathrm{L}$. Adding varied doses of Moringa oleifera $(50 \mathrm{mg} / \mathrm{L}, 100 \mathrm{mg} / \mathrm{L}$, and $150 \mathrm{mg} / \mathrm{L})$ did not make BOD meet the effluent standard set by government (equal to 60 $\mathrm{mg} / \mathrm{L}$ ). The possible reason for BOD increase was due to the presence of natural and organic compounds content of Moringa oleifera. High level of BOD resulted in the depletion of the dissolved oxygen which detrimentally affects on the aquatic life [3][21].

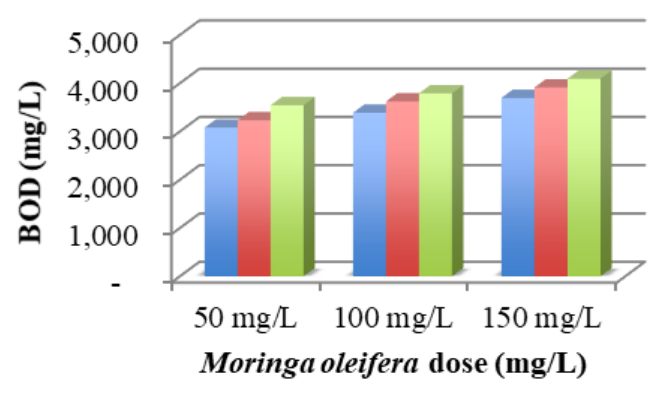

$$
\text { — } 45 \text { minutes }-60 \text { minutes }-120 \text { minutes }
$$

Fig. 3. BCOD increase to Moringa oleifera doses for each detention time

There are two forms of solid found in liquid streams, suspended and dissolved solid. Suspended solid cannot pass the filter, whereas the dissolved solid can pass it. A high concentration of dissolved information indicates that a stream is polluted or unhealthy where many forms of aquatic life can be affected as well [22].

In this study, the initial TDS was around $1236 \mathrm{mg} / \mathrm{L}$. After coagulation flocculation process using Moringa oleifera, TDS decreased to $349.68-477.09 \mathrm{mg} / \mathrm{L}$ at $50 \mathrm{mg} / \mathrm{L}$ addition of Moringa oleifera, $252.87-384.11 \mathrm{mg} / \mathrm{L}$ at $100 \mathrm{mg} / \mathrm{L}$ addition of Moringa oleifera, and 38.55-149.37 mg/L at $150 \mathrm{mg} / \mathrm{L}$ addition of Moringa oleifera (see Figure 4, showing increasing in TDS removal along with an increase in Moringa oleifera concentration). The average TDS removal was $66 \%, 74 \%$, and $92 \%$ at $50 \mathrm{mg} / \mathrm{L}, 100 \mathrm{mg} / \mathrm{L}$, and $150 \mathrm{mg} / \mathrm{L}$ addition of Moringa oleifera respectively. Borehole process using $100 \mathrm{mg} / \mathrm{L}$ Moringa oleifera was able to remove TDS by $86.2 \%$.

TDS removal is caused by Moringa oleifera components consisting basic polypeptides with molecular weights ranging from 6000 to 16000 acting as flocculan which rarefies dissolved solids [23]. The seed kernels of Moringa oleifera contains significant quantities of low molecular weight and water soluble protein carrying positive change to the solution. The coagulation mechanism by Moringa oleifera seeds consists of adsorption and neutralization of colloidal positive charges that attract the negatively charged in water [11][24]. At $\mathrm{pH}$ less than 10 , the MO seeds protein is positively charged and when added to water acts like a magnet binding to the negative charge of particle. There is neutralization of an inter particle bridging between negatively charged proteins in seeds that cause floc formation in flocculation process [19][23][25]. Although the removal increased along with increasing doses of Moringa oleifera, the result did not meet the effluent standard set by government $(50 \mathrm{mg} / \mathrm{L}$ at $50 \mathrm{mg} / \mathrm{L}$ and $100 \mathrm{mg} / \mathrm{L}$ addition of Moringa oleifera). TDS effluent met the standard set at 150 $\mathrm{mg} / \mathrm{L}$ addition of Moringa oleifera at detention time of 120 minutes.

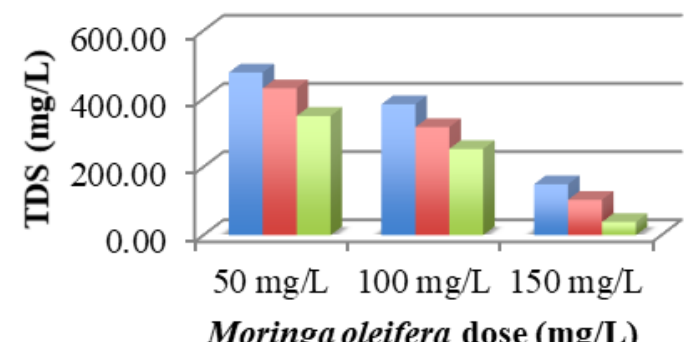

$$
\square 45 \text { minutes } \quad 60 \text { minutes } \quad 120 \text { minutes }
$$

Fig. 4. TDS increase to moringa oleifera doses for each detention time

TABLE III. Rsult OF Multivariate Analysis On The Sedimentation Time, SEDimentation AND InTERACTION BETwEen TIME AND MoRinga

\begin{tabular}{|c|c|c|c|c|c|c|}
\hline \multicolumn{2}{|c|}{ Effect } & \multirow{2}{*}{$\begin{array}{c}\text { Value } \\
1.618\end{array}$} & \multirow{2}{*}{$\begin{array}{c}\mathbf{F} \\
35.980\end{array}$} & \multirow{2}{*}{$\begin{array}{c}\begin{array}{c}\text { Hypothe- } \\
\text { sis df }\end{array} \\
8.000\end{array}$} & \multirow{2}{*}{$\begin{array}{c}\text { Error df } \\
68.000\end{array}$} & \multirow{2}{*}{$\begin{array}{l}\text { Sig. } \\
.062\end{array}$} \\
\hline \multirow{4}{*}{ SoT } & $\begin{array}{l}\text { Pillai's } \\
\text { Trace }\end{array}$ & & & & & \\
\hline & $\begin{array}{c}\text { Wilks' } \\
\text { Lambda }\end{array}$ & .001 & $358.796^{\mathrm{a}}$ & 8.000 & 66.000 & .121 \\
\hline & $\begin{array}{c}\text { Hotelling's } \\
\text { Trace }\end{array}$ & 754.521 & 3018.083 & 8.000 & 64.000 & .082 \\
\hline & $\begin{array}{c}\text { Roy's } \\
\text { Largest } \\
\text { Root }\end{array}$ & 752.895 & $6399.609^{b}$ & 4.000 & 34.000 & .345 \\
\hline \multirow{4}{*}{$\begin{array}{l}\text { SoT * } \\
\text { D_MO }\end{array}$} & $\begin{array}{c}\text { Pillai's } \\
\text { Trace }\end{array}$ & 1.842 & 7.684 & 16.000 & 144.000 & .283 \\
\hline & $\begin{array}{c}\text { Wilks' } \\
\text { Lambda }\end{array}$ & .004 & 31.064 & 16.000 & 101.454 & .386 \\
\hline & $\begin{array}{l}\text { Hotelling's } \\
\text { Trace }\end{array}$ & 66.881 & 131.672 & 16.000 & 126.000 & .068 \\
\hline & $\begin{array}{c}\text { Roy's } \\
\text { Largest } \\
\text { Root }\end{array}$ & 64.957 & $584.617^{\mathrm{b}}$ & 4.000 & 36.000 & .172 \\
\hline
\end{tabular}
OLEIFERA DOSES TO PH, BOD, COD, AND TDS

The results of multivariate analysis showed that sedimentation time and interaction between sedimentation time and Moringa oleifer doses had no significant effect on $\mathrm{pH}$, BOD, COD, and TDS (see Table 2), proved by result of the Pillai's Trace test, Wilks 'Lambda, Hotelling's Trace and 
Roy's Largest Root (significant value was more than 0.05). It indicates that the sedimentation time did not affect the percentage of $\mathrm{pH}, \mathrm{BOD}, \mathrm{COD}$, and TDS removal. The coagulation process occured in successive phases intended to overcome the forces stabilizing the suspended particles in wastewater using collision of particles and growth of floc. If the first step was incomplete, the subsequent step will be unsuccessful as well.

The initial coagulation stage destabilizes the particle charges meaning that the coagulants with opposite charges to the suspended solids were added to the water to neutralize the negative charges on dispersed non-settleable solids and clayproducing organic substances in the wastewater. As soon as the charge is neutralized, the smaller particles were capable on sticking together, while the larger particles were formed through micro-flocs (un-visible) process. Later, water surrounding the newly formed micro-flocs should be clear. Here, when it is not clear to the reasonable percentage, all particles charges were not neutralized and carried out completely. Hence, the increase in maximum concentration was needed to achieve a maximum effluent reduction. Therefore, a high-energy rapid-mix to properly disperse the coagulant and promote particle collisions was needed to achieve maximum coagulation effect and reduction of effluent. Extra-mixing of the water did not affect the bioactive agent, but insufficient mixing left it incomplete. The Moringa seed should be added where sufficient mixing occurred and provided proper contact time in the rapid-mix chamber (2-5 minutes) for appropriate coagulation act [26].

In future studies, it is necessary to develop independent variables, such as variations of rapid stirring, $\mathrm{pH}$ variation and cleaning of oil content in Moringa oleifera seeds to increase the effectiveness of coagulation flocculation. Variations in $\mathrm{pH}$ values can be done by combining Moringa oleifera with alum. In addition, it is necessary to keep an optimum dose assessment for the processing of batik industry wastewater as an independent variable. This was done because the excessive use of Moringa oleifera caused the saturation in the polymer bridge site and re-stabilization of the destabilized particles due to insufficient number of particles forming bonds between particles [6][10]. While the sedimentation time was set for 2 hours (referring to this study). Because this is the optimal time obtained to remove all pollutant parameters contained in batik industry wastewater, due to the floc formed where is small or unable to settle and it can be overcome by providing longer sedimentation time [12].

\section{CONCLUSIONS}

The results showed that independent process of flocculation-coagulation was proved to be ineffective in batik industrial wastewater treatment. From four variables arranged ( $\mathrm{pH}, \mathrm{BOD}, \mathrm{COD}$, and TDS), only $\mathrm{pH}$ variable met the effluent standard set by government. For other two variables (BOD and COD), although increased in its value, they did not meet the standard set by government. The BOD and COD increases were probably caused by the oil content that was not extracted from seeds. While TDS variable had significant reduction $(66 \%-92 \%)$, however it did not meet effluent standards set by government. Based on these results, the future research should add an independent variable such as variations of rapid stirring, variations in $\mathrm{pH}$, or variations in oil content, rather than giving variation in doses of Moringa oleifera. So, the effectiveness of the independent process of coagulation-flocculation in wastewater treatment of the batik industry can be seen. In addition, it is necessary to study the potential combination of biological treatment units with coagulation flocculation to optimize various pollutants in batik industry wastewater.

\section{REFERENCES}

[1] I.S. Abdulraheem, A.R. Olapipo, and M.O. Amodu, "Primary health care services in Nigeria: Critical issues and strategies for enhancing the use by the rural communities," J. Pub. Health Epidemiol., vol. 4, no. 1, pp. 5-13, 2012.

[2] B.V.N.D.A. Tangahu, "Uji Penurunan Kandungan BOD, COD, Dan Warna Pada Limbah Cair Pewarnaan Batik Menggunakan Scirpus Grosuss Dan Iris Pseudacorus Dengan Sistem Pemaparan Intermittent," J. Sains dan Teknol. Lingkung., vol. 8, no. 2, pp. 121-130, 2016.

[3] T.C.Shan, M. Al Matar, E.A. Makky, and E.N. Ali, "The use of Moringa oleifera seed as a natural coagulant for wastewater treatment and heavy metals removal," Appl. Water Sci., vol. 7, no. 3, pp. 1369-1376, 2017.

[4] O. Nkwonta, "A comparison of horizontal roughing filters and vertical roughing filters in wastewater treatment using gravel as a filter media," Int. J. Phys. Sci., vol. 5, no. 8, pp. 1240-1247, 2010.

[5] S. Suhartini, N. Hidayat, and E. Rosaliana, "Influence of powdered Moringa oleifera seeds and natural filter media on the characteristics of tapioca starch wastewater," Int. J. Recycl. Org. Waste Agric., vol. 2, no. 1, pp. 1-11, 2013.

[6] H. Hendrawati, I.R. Yuliastri, Nurhasni, E. Rohaeti, H. Effendi, and L. K. Darusman, "The use of Moringa Oleifera Seed Powder as Coagulant to Improve the Quality of Wastewater and Ground Water," IOP Conf. Ser. Earth Environ. Sci., vol. 31, no. 1, pp. 1-11, 2016.

[7] Z. Othman, S. Bhatia, and A.L. Ahmad, "Influence of the Settleability Parameters for Palm Oil Mill Effluent ( Pome ) Pretreatment By Using Moringa Oleifera Seeds As an Environmental Friendly Coagulant," Int. Conf. Environ. 2008, vol. 2008, no. Icenv, pp. 1-9, 2008.

[8] A. Santos, L. Luz, E. Pontual, T. Napoleão, P. Paiva, and L. Coelho, "Moringa oleifera: Resource Management and Multiuse Life Tree," Adv. Res., vol. 4, no. 6, pp. 388-402, 2015.

[9] T. . V. K. Vijayaraghavan, G.; Sivakumar, "Application of Plant Based Coagulants for Waste Water Treatment," Int. J. Adv. Eng. Res. Stud., vol. 1, no. 1, pp. 88-92, 2011.

[10] M. M. Sapana, G. C. Sonal, and P. Raut, "Use of Moringa oleifera (Drumstick) seed as natural absorbent and an antimicrobial agent for ground water treatment," Res. J. Recent Sci., vol. 1, no. 3, pp. 31-40, 2012.

[11] M. Dehghani and M. H. Alizadeh, "The effects of the natural coagulant Moringa oleifera and alum in wastewater treatment at the Bandar Abbas Oil Refinery," Environ. Heal. Eng. Manag., vol. 3, no. 4, pp. 225-230, 2016.

[12] E. Arnoldsson, M. Bergman, N. Matsinhe, and K. M. Persson, "Assessment of drinking water treatment using Moringa oleifera natural coagulant," Vatten, vol. 64, pp. 137-150, 2008.

[13] M. Franco, G. K. e Silva, and J. E. S. Paterniani, "Water treatment by multistage filtration system with natural coagulant from Moringa oleifera seeds," Eng. Agrícola, vol. 32, no. 5, pp. 989-997, 2012.

[14] M. J. M. Silva and A. R. Paterniani, José Euclides Stipp Francisco, "Application of Moringa Oleifera natural coagulant for clarification and disinfection of treated wastewater in wetlands and multistage filtration," African J. Agric. Res., vol. 8, no. 24, pp. 3102-3106, 2013.

[15] APHA/AWWA/WEF, "Standard Methods for the Examination of Water and Wastewater," Stand. Methods, p. 541, 2012.

[16] J. E. S. Paterniani, T. a P. Ribeiro, M. C. Mantovani, and M. R. Sant'anna, "Water treatment by sedimentation and slow fabric filtration using Moringa oleifera seeds," African J. Agric. Res., vol. 5, no. 11, pp. 1256-1263, 2010.

[17] N. Eman, C. Tan, and E. Makky, "Impact of Moringa oleifera Cake Residue Application on Waste Water Treatment: A Case Study," J. Water Resour. Prot., vol. 6, no. May, pp. 677-687, 2014. 
[18] WHO, "Guidelines for Drinking-water Quality," vol. 1, no. 3, pp. 104-8, 2011.

[19] F. K. Amagloh and A. Benang, "Effectiveness of Moringa Oleifera Seed as Coagulant for Water Purification," African J. Agric. Res., vol. 4, no. 2, pp. 119-123, 2009.

[20] J. Sánchez-Martín, J. Beltrán-Heredia, and J. A. Peres, "Improvement of the flocculation process in water treatment by using Moringa oleifera seeds extract," Brazilian J. Chem. Eng., vol. 29, no. 3, pp. 495-501, 2012.

[21] O.G. Irenosen, A.A. Festus, and A.F. Coolborn, "Water quality assessment of the Owena Multi-purpose Dam, Ondo State, southwestern Nigeria.," J. Environ. Prot. (Irvine,. Calif)., vol. 3, no. 1, pp. 14-25, 2012.

[22] P. R. R, S. Jagadalesuryakant, G. A. A, and M. A. V, "Use of Moringa Oleifera ( Drumstick ) seed as Natural Coagulant for Well \& Bore well Water Treatment," Int. J. Eng. Res. Technol., vol. 10, no. 1, pp. 336340, 2017.
[23] S. Subramanium, V. Nand, M. Maata, and K. Koshy, "Moringa oleifera and other local seeds in water purification in developing countries," Res. J. Chem. Environ., vol. 15, no. 2, pp. 135-138, 2011.

[24] I. R. Eri, W. Hadi, and A. Slamet, "Clarification of Pharmaceutical Wastewater with Moringa Oleifera: Optimization Through Response Surface Methodology,” J. Ecol. Eng., vol. 19, no. 3, pp. 126-134, 2018.

[25] G. S. Madrona, I. G. Branco, V. J. Seolin, and B. De, "Evaluation of extracts of Moringa oleifera Lam seeds obtained with $\mathrm{NaCl}$ and their effects on water treatment," Acta Sci. Technol., vol. 34(3), no. May 2012, pp. 289-293, 2015.

[26] M. Sulaiman, D. Zhigila, K. Mohammed, D. Umar, A. Babale, and F. Abd Manan, "Moringa oleifera seed as alternative natural coagulant for potential application in water treatment: A review," J. Adv. Rev. Sci. Res., vol. 30, no. 1, pp. 1-11, 2017. 